\title{
Tourist clusters from Flickr travel photography
}

José A. Donaire PhD

Raquel Camprubí PhD

Nuria Galí PhD

Faculty of Tourism- University of Girona

PI. Ferreter Mora, 1

17071 Girona (Spain)

Tel: +34972419715

ja.donaire@udg.edu

raquel.camprubi@udg.edu

nuria.gali@udg.edu 


\section{Highlights:}

- We explore tourists' digital photos shared on the social network Flickr, focusing on a specific case study (The Boí Valley, Spain).

- We identify 4 groups of tourists using cluster analysis.

- Cluster analysis shows that each group is interested in a certain selection of potential sights.

- Cluster analysis also demonstrates that tourists share a particular way of looking at these sights. 


\section{Tourist clusters from Flickr travel photography.}

\section{Introduction}

The tourism image of a destination has received considerable interest in academic literature over the past three decades (Dilley, 1986; Etchner \& Ritchie, 1991; Dann, 1996; Mackay \& Fesenmaier, 1997; Baloglu \& McCleary, 1999; Andreu, Bigné \& Cooper, 2000; Jenkins, 2003; Garrod, 2009). Tourism image is an essential factor when tourists select a destination; it also conditions both visitors' perception of the place and their behaviour. In order to understand consumer behaviour in destinations better, it is crucial to understand the mechanisms that explain how tourist images are formed and reproduced.

In the vast field of tourism image, photography plays a very important role. Photo shots are a prime element of the image perceived by visitors and also a path to understanding processes in the symbolic construction of destinations. Every time a tourist takes a picture, the value given to what is photographed is explicitly expressed; we can therefore consider each photograph to be an exercise in tourism semiotics.

Access to these images has always been a methodological difficulty. Fortunately, in the digital age many tourists have adopted the habit of sharing their pictures online and labelling them with geographical tags, making it relatively easy to access a representative catalogue of photographs for a given destination. When tourists upload their pictures onto Internet, they make a selection of pictures that they want to share, and at the same time they also choose a limited number of elements (monuments, visited places, landscapes...) from all of those that are photographed along their route. So, this process is a "double filter".

Previous research has essentially been focused on the most salient elements of tourist pictures of specific destinations. For example, Mackay and Couldwell (2004) analysed 1,642 pictures from 129 tourists using Visitor-Employed Photography (VEP) methodology to collect data. They conducted a content analysis approach, 
giving as a result 50 subjects classified in 7 categories. A final classification leads to an understanding of the main elements that catch the attention of tourist photographers.

However, none of the previous studies consider the principal common features of the tourists' photographic gaze. Perhaps this perspective was not taken into account because the previous studies focused specifically on determining the elements of the pictures and not the photographer gaze. For this reason, this paper aims to determine if there are different ways of seeing a tourism destination; and attempts to detect tourist clusters sharing similar photographic criteria. So, considering previous studies in this field and that "photography has been crucial in developing the tourist gaze" (Urry \& Larsen, 2011:186), this study gives an in-depth understanding of the patterns of this gaze. This is particularly useful from a managerial perspective, as insight give a deeper understanding to tourist image as a factor conditioning decision-making processes. In turn, identifying profiles of tourists' gaze in a destination allows for better marketing and segmentation strategies.

Therefore, this study shows the possibilities of analysing photographs of a tourist destination shared on the social network Flickr, the most popular online photosharing application (Stylianou-Lambert, 2012), using photographs, taken by a sample of tourists in the Boí Valley (Spanish Pyrenees) as a case study. The method of analysis used was content analysis to determine pictures' features and cluster analysis in order to find evidence of profiles of tourists' gazes. Finally, the conclusions focus on some practical aspects of this study, its limitations and guidelines for future research.

\section{Literature review}

\subsection{Tourist image conceptualization}

Numerous authors have attempted to define and conceptualise the tourist image. One of the most widely accepted definitions is that proposed by Crompton (1979: 18), which determines a tourist image as "the sum of beliefs, ideas, and impressions that a person has of a destination". If we turn our attention to the numerous 
definitions provided by other authors, a general consensus is observed in determining that the image of a destination entails the existence of prior knowledge and impressions of the place in question (Fakeye \& Crompton, 1991; Kotler, Haider \& Rein, 1994; Mackay \& Fesenmaier, 2000).

Images are formed from messages transmitted consciously or unconsciously by a number of different agents. Gartner (1994) identified 4 groups of agents involved in forming the tourist image: induced agents (spokespeople and journalists), highlighting agents (tourism managers and travel agents, who create the tourist image intentionally), autonomous agents (newspapers, books, art, and so on) and organic agents (the tourists themselves, who, although contributing to forming the tourist image, do not have this as their aim).

Furthermore, forming the tourist image in individuals' minds requires a process of internal reflection influenced not only by the sources of information consulted, but also by numerous personal variables such as psychological and socio-cultural characteristics, motivations, needs, and prior experiences, among others. In respect of this, Baloglu \& McCleary (1999) determined that variety and types of information source, as well as age and level of education, are all variables that affect the cognitive evaluation of the tourist image. All of these factors together make the individual's tourist image highly subjective on both an individual (Gunn, 1988; Barroso, Martín \& Martin, 2007) and group level (Crompton, 1979).

The tourist image is positioned as an element of extreme importance that conditions tourist behaviour and the decision-making process, as demonstrated by numerous studies (Stabler 1988; Chon, 1990; Etchner \& Ritchie, 1991; Prebensen, 2007). It is a key element of the tourist experience. Following the 7 stages of the tourist experience proposed by Gunn (1972), the perceived image evolves over time as the tourist moves from using generic information regarding the destination (organic images) to using sources of information that have been previously designed to capture their attention (induced images).

Following the parameters proposed by Gali \& Donaire (2005), the image the tourist has at this stage is an a priori one, which evolves after the tourist's arrival at the 
destination to become a perceived image in situ. However, once tourists have returned from their trip, they have a complex perceived image (Gunn, 1972), which is constituted by memories of the experience they had at the destination (Leisen, 2001). Specifically, photographs play the role of recalling the experience they had on the trip and are a summary of the tourist's perceived image. All tourists experience the tourist image differently, which is why Dann (1996: 52), in his study on the tourist image of Barbados, argues that "two people cannot see a destination in exactly the same way". Although some elements will coincide, others will be personal to each individual.

\subsection{Photography and tourism}

Numerous researchers have focused on analysing the relationship between photography and tourism (Albers \& James, 1988; Markwell, 1997; Jenkins, 2003; Mackay \& Couldwell, 2004; Garrod, 2008). Urry (1990) proposes a hermeneutic circle of representation, in which tourists are both consumers and reproducers of the images they have previously perceived, resulting in "a continuous reproduction and recirculation of photographic images - both iconic and everyday - that perpetuate the tourist image held by society" (Garrod, 2009: 347). "In this process, tourists reaffirm the privileged position of photography as a source of their own awareness" (Albers \& James, 1988: 136). Diverse authors have supported this view (Hall, 1997; Caton \& Santos, 2008; Stylianou-Lambert, 2012).

For Sontag (1973), a photographic act is a means of certifying the experience, that is, irrefutable proof of the place visited. The photograph allows the ephemeral nature of the moment to be captured (Galí \& Donaire, 2005), allowing the image to be linked to the real world as something tangible, a material proof (Markwick, 2001), documenting the sequence of consumption (Sontag, 1973), and converting it into a vehicle that allows the everyday consumption of the experience. "[Photography] has been used to gain understanding of the tourist experience" (MacKay \& Couldwell, 2004), and "appears to be believable as a direct representation of reality, a 'true' reflection of actual places, people, and events" (Markwick, 2001). For Albers and James (1988), on the other hand, presenting photography as a window on reality is an illusion, as it is hardly likely to provide an objective representation. 
According to Markwick (2001), photographs have the property of freezing time and space forever, decontextualising the photographed element and fragmenting it. Thus, "these fragments come to stand for the whole or the essence of things, often in representations which may extend, symbolically, far beyond that which is photographed" (Markwick, 2001:420). Thus, photography is the personal view of each individual, which is often seen as being stereotyped by images perceived previously, and therefore "travel photographs that are mass produced are especially influential arbitrators of sight and knowledge. In subtle as well as obvious ways, these photographs not only formulate and institutionalize what tourists see and how they see it, but also how they know and understand what they see" (Albers \& James, 1988:136). In short, photography is posited as an essential part of the trip. Markwell (1997), in his study on the photographic behaviour, determined that as the days pass tourists take fewer photographs due to the fact that they make a change from "looking at" to "involvement in".

Most studies that analyse the photographic ritual highlight predictable tourist behaviours. Thus, for example, Harrison (2004) identifies photographic patterns, some with socially constructed behaviours. Bourdieu (2003) and Urry (1990) also believe that there is a tourist gaze that practically forces visitors to focus their photographic experience on certain items and therefore ignore others. This tendency is contradicted by studies showing that contemporary tourists are much more diverse and heterogeneous. For example, Barroso and Martín (2007) have demonstrated the relationship between heterogeneity in tourists and diversity in the perceived image; Pan and Li (2011) have incorporated the long tail concept to the tourist image of China and have shown that once the universal icons of the destination have been mentioned, the image tends to become considerably more dispersed.

Traditionally, showing photographs to friends and family and relating the holiday experience followed returning home after a trip. However, the dawning of the digital age has brought with it a new reality. Firstly, the appearance of digital cameras has led to a notable increase in the number of photographs per trip, particularly due to the lower cost entailed (Donaire \& Galí, 2011). And secondly, "travel photo sharing [is no longer] a private endeavour, with pictures assembled into albums and shared 
with a small audience known well by the person" (Lo et al., 2011:726), instead it has become a social event. New digital platforms have opened the doors to the social sharing of private photographs. Web 2.0 websites, including Flickr, Picasa, Facebook or Pinterest, allow photographs to be shared online, often just a few moments after taking them, which suggests a democratisation in the process of creating and disseminating images (Lo et al., 2011).

The relevance of this new context lies not only in the social changes produced by digital photography, but also in the fact that on Web 2.0, website users become the protagonists of the content generated. They also play a key role in disseminating and communicating their experience and their impressions and thoughts regarding the destination (Camprubí, Guia \& Comas, 2013). Basically, "virtual communities are gradually becoming incredibly influential in tourism as consumers increasingly trust their peers better, as opposed to marketing messages" (Buhalis \& Law, 2008). This is possibly because they represent the new form of word of mouth, which generates more credibility among peers. It is within this context that Destination Marketing Organisations (DMOs) have increasingly started to reconsider the need to manage all of this content online (Schmallegger \& Carson, 2008), not only as a form of controlling negative comments, but as a means of benefiting from its inherent advantages in promoting the destination.

The widespread use of social photo networks has opened up a new field of research in tourist photography, as it is now possible to access an immense catalogue of images organised according to tags and, in some cases, even geolocalised. The earliest and most widely accepted method of accessing and analysing tourist pictures has always been the Visitor-Employed Photography (VEP) research technique (Haywood, 1990; Mackay \& Couldwell, 2004; Canton \& Santos, 2008; Garrod, 2008, 2009). VEP is a technique whereby tourists provide researchers with photos they have taken on a trip in order for them to analyse the perceived image. It requires participant involvment, which may influence tourist behaviour and the size of the sample, reducing it to some degree. Another technique using photographs is photo elicitation, however this method is based on open-ended interviewing where the interview is guided by images, some authors have used it to investigate tourist's experiences (Jenkins, 1999). 
However, we can find some innovative research that has already used social networks as a source of information, such as the study conducted by Crandall, Backstorm, Huttenlocher and Kleinberg (2009), which analysed the "photographic trace" left by visitors; or that conducted by Popescu, Grefenstette and Moëllic (2009), who analysed trip-related information from Flickr. Also, more recent studies, such as those carried out by Stepchenkova and Zhan (2012) analysing the image of Peru from pictures of DMO's sites and Flickr; Stylianou-Lambert (2012), who examines tourists' photographic representations in Ciprus from Flickr and Picasa; that of Donaire and Galí (2011) analysing Barcelona's perceived image from the Flickr community; and Pengiran-Kahar et al. (2010), who studied Arabian Muslim travel photos on Flickr.

Although all these studies analyse the perceived tourist image online, none of them focuses on analysing whether there are different profiles of photographers' gaze, or if all tourists photograph exacly the same elements from the same perspective. Thus, a method to analyse this aspect needs to be established, in order to give a wider understanding of this approach to perceived tourist image.

\section{Methodology}

The purpose of this study is to identify groups of tourists (clusters) with very different views of the same place by analysing photographs they have posted on Flickr. In this case, the tourist destination is the Boí Valley (Spain). What we are actually aiming to do is understand how different tourist photographers see the valley by analysing the way they take photographs. We have therefore analysed a systematic random sample of 1,786 photographs taken by tourists to the valley who posted their pictures on Flickr. The sample has a margin of error of $2.2 \%$, at a level of confidence of $95 \%$ and maximum indeterminacy. 


\subsection{Study site}

The Boí Valley is a municipal district situated in the high Pyrenees, in the region of Catalonia (Spain). The valley contains heritage sites of notable historical and artistic value. In fact, a group of Romanesque buildings in the Boí Valley were declared a UNESCO World Heritage Site in 2000. Also, it is an entry point to Aigüestortes and Lake Sant Maurici National Park: one of the 14 national parks in the whole of Spain, and the only one in Catalonia. Furthermore, the Boí Valley also has first-class tourist services, such as the ski resort "Boí Taull".

Figure 1. Map of the Boí Valley

In fact, the Boí Valley is an excellent research laboratory, with all the elements that comprise the tourist experience in one single place: a rich heritage, exceptional natural features, great tourist services and a rich and living culture. In addition, the Boí Valley is similar to other European destinations such as Aosta and the Po Valley (Italy), Ariège (France) or the Lim Valley (Crotatia), allowing comparisons in the future.

\subsection{Data collection}

The source used for our analysis is photographs of the Boí Valley appearing on Flickr. This is a large website of images, where tourists store images taken on their trip to a destination.

Flickr, like other similar social networks on the Internet, is becoming a powerful database for analysing the tourism image of destinations worldwide, as demonstrated by some recent studies (Pengiran-Kahar et al., 2010; Angus et al., 2010; Donaire \& Galí, 2011; Stepchenkova \& Zhan, 2012; Stylianou-Lambert, 2012). Flickr contains over 14,000 photographs of the Boí Valley taken and uploaded under 367 different nicknames, some were tourists, but others were not. Pictures were selected using a randomised sampling method, specifically, from automatic, randomly generated numbers. Random sampling significantly reduces the potential bias caused by the subjectivity inherent in the method. From the information 
provided by users on their Flickr profile, it was possible to discriminate between those users who were visitors to the valley and those who were residents, rejecting the latter. In cases where the nickname was not clear enough, the user was rejected and the automatic random generation of numbers continued and chose the next photograph. It is true that not all tourists take photos and even fewer share them on the Internet using sites like Flickr. The sample is only representative of those tourists who chose to select some of their photographic images and share them on this site.

In contrast to other studies that have used Flickr (Pengiran-Kahar et al., 2010; Stepchenkova \& Zhan, 2012; Stylianou-Lambert, 2012), all of the images shared by the selected users (nicknames) have been analysed. Firstly, this avoids the bias caused by differences in the number of images captured by each tourist photographer. If the sample images are analysed regardless of user, the result is very much conditioned by the most active nicknames. Furthermore, linking the images with the nicknames that share them provides information of paramount importance, such as the percentage of tourists who take at least one photo of a church in the valley.

\subsection{Data analysis}

Data analysis was carried out in two stages. First of all, a content analysis was conducted to define characteristics of pictures posted on Flickr. Content analysis can be defined as an observational research method that is used to systematically evaluate the symbolic content of all forms of recorded communications (Kolbe \& Burnett, 1991; Hall \& Valentin, 2005). It should be objective, systematic and general in order to guarantee the reliability and replicable character of studies (Holsti, 1968). "Content analysis has occupied a privileged position in the social sciences as a method for studying photographic media" (Albers \& James, 1988: 145), being used by a great number of authors to analyse destination image (Dilley, 1986; Camprubí, Guia \& Comas, 2012; Pritchard \& Morgan, 1995, 1996; Santos, 1998; Galí \& Donaire, 2005; Govers \& Go, 2005; Choi, Letho \& Morrison, 2007). Generally, a categorisation is used in order to systematise content analysis, and a set of suitable parameters and rules established to maintain congruency and validity of data (Albers \& James, 1988; Holsti, 1968; Kolbe \& Burnett, 1991; Kassarjian, 1977). 
In this study, four categories were used to classify pictures based on previous research (Camprubí et al., 2012; Dilley, 1986; Donaire \& Galí, 2011; Galí \& Donaire, 2005; Govers \& Go, 2005; Pritchard \& Morgan, 1995; Santos, 1998). These categories were nature, heritage, culture and tourist services (see Table 1 for detailed descriptions), and were chosen on the basis of two criteria: firstly, they were four of the most common categories for analysing tourism image; and secondly, they are the four categories that include the main tourist characteristics of the destination used as a case study. Albers \& James (1988) state that categories may vary from one study to another depending on the particular interests of researchers and the data set being utilised.

Table 1: Description of categories

Furthermore, some authors also mention the multi-dimensionality of pictures as a critical issue in content analysis (Camprubí et al., 2012; Galí \& Donaire, 2005 Pritchard \& Morgan, 1995). Thus, "eye-catchers" were considered in order to properly classify each picture. "Eye-catchers" are considered "as an illustration where 50 per cent or more of the image is occupied by an eye-catching device designed to grab attention" (Pritchard \& Morgan, 1995: 28).

In addition to the above, three other items were gathered (see Table 2) in order to provide a more holistic description of what is represented in the pictures analysed. Firstly, the degree of human presence was considered; that is, whether there were tourists, residents, tourists and residents together, or nobody appeared in the photograph. Tourists were distinguished from residents by means of a qualitative analysis of the images: the attitude towards the camera is fundamental here. Tourists play a role in front of the camera and act according to a specific convention: they smile, facing the camera, posing, among other things (Stylianou-Lambert, 2012); residents, on the other hand, tend to appear in a spontaneous, casual pose. In cases where it was not possible to identify whether the figure was a tourist or a resident, the image was rejected. 
Secondly, cameras zoom. We analysed whether the image was a close-up (e.g. a church bell tower), the element itself (the whole church), the element in its context (e.g. the church and the village), or panoramic (e.g. the mountains and the valley). In other words, we determined the focus of the camera. This information is very important when studying how photographs are taken, because it ascertains which parts of the photographed objects (i.e. monuments) catch the attention of photographers, for example the whole monument or some part(s) of the monument (Donaire \& Galí, 2011). Finally, it was noted whether the photograph was of an interior or exterior space.

Table 2: Items analysed in the content analysis

In order to guarantee the reliability of the content analysis, an independent coder categorised each picture according to the pre-established rules (categories, eyecatchers, degree of human presence, zoom and interior/exterior). The authors reviewed and validated each picture classification independently. When divergences were found, the matter was discussed until a final agreement was reached.

In the second stage, a descriptive analysis was first conducted in order to identify which elements comprise the tourist image of the valley, including various categories, degree of human presence, zoom and interior/exterior. Then a cluster analysis was carried out in order to demonstrate that the tourist gaze is not homogenous for the valley.

Cluster analysis is a multivariate technique that allows the identification of groups that have a hard intra-group homogeneity and a high level of inter-group heterogeneity (Aldenderfer \& Blashfield, 1984; Hair, 1998). Ward's method was the algorithm selected for data clustering, based on the squared Euclidean distance (Hair, 1998). Ward's method ensures that there is a minimal loss of information in the fusion of elements, creating clusters with a similar number of objects (Hair, 1998). Once we obtained the clusters, an ANOVA test was carried out in order to determine differences between them. 


\section{Results}

There are some common characteristics that generically explain how the valley is photographed. In order to identify general patterns, we considered the four criteria presented in the methodology section: distribution of the diverse elements captured according to the defined categories, the degree of human presence in the images, the zoom or camera focus, and the type of space photographed (exterior or interior). The cluster analysis shows, however, that beyond the general criteria homogeneous groups exist that share specific ways of "looking at" the place. Combining the different items listed creates these groups. The results take into account the most photographed elements (content), and also how these elements are observed (perspective).

\subsection{The most photographed elements by categories}

Findings (Figure 2) reveal that $94 \%$ of tourist photographers to the Boí Valley take at least one photograph of a heritage element and $62 \%$ of tourists take at least one photograph of a natural element. Less frequent are those tourist photographers $(18 \%)$ who take at least one picture of a tourist service, or a cultural demonstration $(6 \%) .$.

Figure 2. Tourists (\%) who photographed a minimum of one element by categories

However, the above data only takes into account whether tourist photographers took at least one photograph of each element. Some elements tend to be more photographed than others. For example, if a photographer took 100 shots, he or she would take 63.5 of heritage elements, 34 of natural elements, 1.5 of culture and only one of tourist services.

Results show that the perceived image of the valley is linked to heritage more than nature - which plays a more secondary role - or ethnography and services, which play even less of a role. This is a surprising finding, because although it is true that 
the valley has one of the most important groups of Romanesque buildings in Europe, it is also true that it is the only national park in the region and has a rich living culture. However, the tourist gaze here focuses exclusively on ecclesiastical heritage.

\subsection{The degree of human presence in tourists' photographs}

A further element of analysis in the study was to determine the degree of human presence in the tourists' images, as tourist scenes are often presented as empty spaces, devoid of people. Various studies have analysed the presence of individuals in photographic images. In some cases, an absence of individuals has been highlighted, especially in photos taken of European heritage destinations (Albers \& James, 1988; Garrod, 2009; Galí, 2006); residents appear in images much more frequently in destinations considered exotic or allocentric (Caton \& Santos, 2008; Crang, 1997); and images of the tourists themselves are more common in tourist destinations where there is social interaction between trip participants (Markwell, 1997).

As mentioned above, we have classified the images into four subgroups: photographs without people, photographs with the tourists themselves, photographs with locals, and, finally, photographs with locals and tourists.

In general terms, we might say that the images show the Boí Valley to be a place, which is largely free of people, with neither tourists nor residents present. In fact, this is not unusual (Griffone \& Weiler, 1992; Markwell, 1997; Galí, 2006). One reason for this is that tourists have inherited the romantic ideal of tourism consumption based on the individual consumption of places, meaning that any human presence represents some form of alteration (Barthes, 1957; Saïd, 1978; Urry, 1990). This is also why images emitted by the places themselves have eliminated any trace of humanity: empty churches, deserted valleys, old quarters that resemble open-air museums, and so on.

The most frequent circumstance is for tourist photographers to take pictures without people in them (54\%). Some 30\% combine images with no one in them and images with themselves in them. Only $4 \%$ of tourist photographers combine pictures with no 
human presence and pictures with locals. The remaining $4 \%$ play with the different options: all types of photographs.

Table 3. Tourists (\%) by degree of human presence in photographs taken

If we therefore imagine a typical tourist photographer and study all the images he/she captures, we find that $89 \%$ of the images are free of human presence; the tourists themselves appear in $9 \%$ and locals in $2 \%$. In other words, for every 10 photographs taken in the Boí Valley, nine have no trace of human presence.

The lack of humans in images is frequent in western destinations, but in the case of the Boí Valley the values are very extreme. This result demonstrates that the phenomenon of "removing human presence" from the cultural and natural space is found in more scenic places, which are still perceived as inhabited places, especially in classic European destinations.

\subsection{The zoom}

The distance from which images are taken varies greatly. Sometimes tourists opt to capture only the detail, and then the zoom is used to get as close as possible to the object; on other occasions, however, the interest is in the beauty of the landscape as a whole and the shot is wider (wide angle). Therefore, each image was classified into four subgroups as reported in Table 4.

Table 4. Tourists (\%) according to how they took the photograph (focus)

The data are distributed much more heterogeneously here. Some $33 \%$ of tourists photographed elements in context. In this case, the visitor attempts to frame what they are visiting within a context that allows its easy recognition. It is supposed that, in a place like the Boí Valley, it makes sense not to disassociate nodes from their environment, as the similarity of the churches means their contextualisation is necessary for recognition. Around $29 \%$ opted for the node on its own, that is to say, the element out of context. Furthermore, we found that these are mainly cases of heritage elements. Tourism practice in the valley demonstrates a fairly nodal 
behaviour (62\% of all visitors photographed almost one node). Tourists tend to consume nodes more than semiological spaces, a strange finding for a place where nodes have the same value as semiological spaces.

In addition, $24 \%$ of visitors photograph panoramas. Most of the images of decontextualised spaces are images of nature.

Finally, $14 \%$ of tourists captured a fragment of an element. Heritage elements have numerous details, which often capture the attention of the photographer.

The most relevant aspect of this is that the strategies adopted suit the object being photographed; that is, while some spaces have a greater tendency to be photographed as a whole, others generate a significant number of detailed images. The type of element being photographed conditions the use of the zoom and the interest it arouses in the tourist gaze.

\subsection{Captured spaces}

A further aspect considered in our analysis is the predominance of either interior or exterior photographs. We therefore classified images into two large subgroups. The results show a clear predominance of exterior images. In fact, $90.3 \%$ of the pictures taken by tourist photographers are outdoors, with only $9.7 \%$ indoors.

This result is coherent, taking into account the nature of the place. The Boí Valley is a nature-based destination where historical heritage has a relevant role in the configuration of its landscape. Therefore, the Boí Valley is essentially exterior, based on the attributes of the space that are visible to all visitor photographers; which are photographed alone (a mountain landscape) or jointly with other elements (a church and the mountains as a background).

Generally, interior photographs are of elements inside Romanesque churches, such as images of altars, chapels or, more frequently, the Pantocrator in Sant Climent de Taüll church, an icon from the European Romanesque period. However, it must be pointed out that indoor places are poorly illuminated, this being a technical restriction 
for the majority of tourist photographers. Other issues that also complicate indoor photographs are limited opening times and access fees.

\subsection{Cluster analysis}

The main aim of our study was to identify clusters or groups of tourist photographers by taking into account how they viewed the valley. Previous research on tourist photographs has commonly followed a classification of photograph content, beginning with Dilley (1986) and continued by, among others, Pritchard and Morgan (1996), Santos (1998), Jenkins (2003) Bandyopadhyay and Morais (2005) and Camprubí, Guia and Comas (2009). In other cases, content analysis has been complemented by a semiological analysis so as to interpret the composition of photographed elements (Markwick, 2001; Jenkins, 2003; Galí \& Donaire, 2005). Methodology based on Visitor-Employed Photography (Mackay \& Couldwell, 2004; Garrod, 2008, 2009) provides a highly visual record of place image.

However, very few studies have focused on determining how these elements are viewed; in other words, not only what tourists look at, but also how they look at it. The cluster analysis of tourist photographs in the Boí Valley is based on a combination of the elements and perspectives photographed. We considered the value of every study factor for each of the nicknames used in the analysis: categories, zoom, human presence and type of space. The results of the cluster analysis suggested a four-cluster solution as the most appropriate and coherent. During the cluster analysis the variables culture and services were excluded, as their p-value was higher than .05. In particular, multivariate statistics indicated that significant differences exist between the four clusters. The results of the ANOVA test also demonstrate that the variables included in the models contributed to cluster differentiation (Table 5). The characteristics of the clusters are described and compared below.

Table 5. Cluster analysis results

Cluster A. Global. Global tourist photographers represent $36 \%$ of all tourist photographers in the study, and therefore constitute the most numerous group. This 
group of tourist photographers have a comprehensive view of the area visited, in that they are interested in both natural and cultural elements to a similar degree. In addition, this is also the cluster where the other categories have a greater presence. These are therefore photographers who favour a general view of the area over a specific interest in any one of its parts. This broader view is also evident in the wide range of shot types, as no particular angle is favoured over others. Not only do they observe diverse elements, but also they do so from various perspectives. Therefore, the result is a greater diversity of images that can be explained by the desire to capture the great diversity of the area visited.

Cluster B. Scenic. Tourists who take scenic view photographs comprise $22 \%$ of the whole. One of the most significant characteristics of this cluster is the weight of nature photos, which represent three-quarters of the total and are mainly of Aigüestortes National Park. Of all possible perspectives, this group opts for broad panoramas, which include the mountain skyline or the wide valleys, while images of fragments of natural elements are almost non-existent. These tourists identify the natural space as immense scenery, as if the camera was trying to capture the widest angle possible. Another notable characteristic of this group is the high degree of human presence in the images, almost 30\%. Photographs therefore fulfil a dual function, aesthetic on the one hand and social on the other.

Cluster C. Detail hunters. Detail hunters comprise $22 \%$ of all tourist photographers. These tourists are almost exclusively interested in cultural heritage, and take hardly any photos of natural spaces or tourism services. Nor are any people found in their pictures, as they are always free from human presence, devoid of any trace of either residents or tourists. Detail hunters stand out for their high number of detailed photographs, fragments of elements (a gate, a Romanesque window, a bell tower), combined with images of the element itself. These tourists are interested in World Heritage churches and practically ignore the rest of the space. It is also a cluster that captures the greatest number of interior images, basically interiors of Romanesque churches.

Cluster D. Monument lovers. These make up $20 \%$ of all tourist photographers studied. Practically all of the photographs depict an element of cultural heritage, 
particularly World Heritage churches. As with the previous cluster, most of the images are free from human presence. However, this group differs from the detail hunters in the way they look at heritage. There are no photos of interiors. Neither do they look for fragments, in most cases preferring to capture the whole element, either on its own or in context. All of these elements allow us to identify a tourist who is essentially interested in the monumental image of the different buildings spread throughout the valley.

In short, the four clusters differ in terms of which elements they capture on camera and therefore which elements are of symbolic value to them. Global and scenic tourists are interested in natural landscapes, although they also integrate images of historical heritage, while detail hunters and monument lovers focus almost exclusively on the latter. However, selection of the object is not the only criterion that allows us to identify groups of tourists. Global and scenic photographer tourists differ in how they present individuals in their photographs, this meaning that pictures can be either an aesthetic resource or a social act. They also differ in the perspective of their gaze, which is much more diverse among global tourist photographers. Detail hunters and monument lovers are differentiated in the way they "look at" heritage; while the former capture interior images and award importance to detail, the latter opt for a global view, very close to the image emitted by the valley itself.

\section{Conclusions}

Tourist photographs are a very relevant indicator of the perceived image of a destination. Each time a tourist takes a picture, he is making a selection from among all of the elements that could possibly be photographed and all possible angles. The digital photo has transformed tourists' photography habits; they are now less selective and there is a clear increase in the number of shots taken. In addition, images have adopted a social function, as they are frequently shared on social networks, meaning they have a much higher viral quality. The digital age has probably reduced the hermeneutic circle of images: the distance between the perceived image and the emitted image is increasingly shorter. No doubt this 
process will have consequences for the symbolic construction of destinations, which are exposed to a permanent reconstruction of their image. At the same time, however, photographs shared on social networks allow access to a very extensive catalogue of tourist photographs, which could previously only be obtained using other methods such as VEP.

Analysing a representative sample of photographs taken in the Boí Valley has allowed us to determine the most relevant characteristics of photographs taken by tourist photographers visiting the valley. In fact, tourist photographers do not share all of their images, but rather make a premeditated selection, opting to share some and discard others. The result is a dual filter of their perception of the valley, firstly via shot selection and then their selection from the set of photographed images. The analysis of images shared on social networks contributes to tourism studies, in that it allows visitors' photographic routes to be traced and then resident and tourist patterns to be compared or both the content and perspectives of images to be analysed. It is clear that these analyses may be very useful in studying the image perceived by tourists, and can also be applied to destination management and marketing. It is also worth noting that the photos posted on Flickr do not represent all of the photographs captured by tourists, but only those that have actually been selected for sharing. Although there is some evidence that images on Flickr do coincide with the pictures tourists take on their trips (Stepchenkova \& Zhan, 2012), it would be interesting to study the relationship between pictures taken by tourists on their trips and those posted on the internet.

Furthermore, as outlined in the aim, this paper tries to determine if there are different ways to see a tourism destination. This is a main feature of how the destination is perceived: the different groups of tourist photographers share a particular way of "looking at" the space. Cluster analysis shows us that each group is not only interested in a certain selection of the potentially interesting sights, but that they also share a particular way of looking at them. Thus, groups of tourist photographers are not only differentiated by what they look at, but also how they look. Specifically, four groups of tourist photographers to the valley were identified: global tourist photographers, who take an overall view of the space; scenic, who capture panoramas, particularly of natural spaces, and accept the presence of tourists and 
residents; detail hunters, who perceive a fragmented view of the cultural spaces; and monument lovers, who portray the churches in their entirety and always from the exterior.

Therefore, this paper contributes to academic literature in two different ways. Firstly, by stating that different profiles of tourist photographers' gaze exist, in particular in cultural and nature-based destinations. Secondly, methodological contribution to the analysis of these different profiles has been carried out. Although cluster analysis is extensively used in social sciences and tourism segmentation, this case differs from other studies in the type of variables used to determine differences in tourist photographers' gaze. This means the clusters are formed from both photographed objects and the most salient characteristics of each of the photographs. In this context, future research should take this approach and methodology to analyse other types of destinations such as urban destinations or sun and beach destinations, in order to find out if similar clusters are formed.

Some limitations of this study must be also identified. Firstly, not all tourists visiting the valley take photos and share them online. Therefore, this is not a study of all tourists but only tourist photographers who share their photographs on Flickr. However, it can be seen that the tourist photographer is making a selection to share with others from all the pictures taken. Secondly, none of the images analysed include very private acts.

Considering that the classical means of tourism image dissemination (travel guides, brochures, etc.) are competing against the new social network platforms (Lo et al. 2011), future research should concentrate on an in-depth analysis of the internal processes which make individuals select certain pictures to upload on the Internet; as well as identifying their socio-demographic characteristics and differences between users and non-users of this communication tool. 


\section{References}

Albers, P., \& James, W. (1988) Travel photography, a methodological approach. Annals of Tourism Research, 15(2), 134-158.

Aldenderfer, M.S., \& Blashfield, R.K. (1984) Cluster Analysis. Newbury Park: Sage. (Series: Quantitative Applications in the Social Sciences).

Andreu, L., Bigné, J.E., \& Cooper, C. (2000) Projected and perceived image of Spain as a tourist destination for British travellers. Journal of Travel and Tourism Marketing, 9(4), 47-67.

Angus, E., Stuart, D., \& M. Thelwall, M. (2010) Flickr's potential as an academic image resource: An exploratory study. Journal of Librarianship and Information Science, 42(4), 268-278.

Baloglu, S., \& McCleary, K.W (1999) A model of destination image. Annals of Tourism Research, 26(4), 868-897.

Bandyopadhyay, R., \& Morais, D. (2005) Representative Dissonance. India's Self and Western Image. Annals of Tourism Research, 32(4), 1006-1021.

Barthes, R. (1957) Mythologies. Paris: Le Seuil [English translation, 1972, Mytholgies, London: Cape]

Bourdieu, P. (2003) Participant Objectivation. Journal of the Royal Anthropological Institute, 9(2), 281-294.

Barroso, C., Martín, E., \& Martin, D. (2007) The influence of market heterogeneity on the relationship between a destination's image and tourists' future behaviour. Tourism Management, 28(1), 175-187. 
Buhalis D., \& Law, R. (2008) Progress in information technology and tourism management: 20 years on and 10 years after the Internet-The state of eTourism research. Tourism Management, 29(4), 609-623.

Camprubí, R., Guia, J., \& Comas, J. (2009) Managing induced tourism image: Relational patterns and the life cycle. Tourism, 57(3), 241-258.

Camprubí, R., Guia, J., \& Comas, J. (2013) The new role of tourists in destination image formation. Current Issues in Tourism, Doi: 10.1080/13683500.2012.733358.

Camprubí, R., Guia, J., \& Comas, J. (2012) Analysing Image Fragmentation in Promotional Brochures: A case Study in two Urban Destinations. Journal of Hospitality \& Tourism Research. Doi: 10.1177/1096348012451451.

Caton, K., \& Santos C.A. (2008) Closing the hermeneutic circle? Photographic Encounters with the Others. Annals of Tourism Research, 35 (1), 7-26.

Chon, K.S. (1990) The role of destination image in tourism: A review and discussion. Tourism Review, 45(2), 2-9.

Choi, S., Letho, X.L., \& Morrison, A.M. (2007) Destination image representation on the web: Content analysis of Macau travel related websites. Tourism Management, 28, 118-129.

Crandall, D., Backstorm, L., Huttenlocher, D., \& Kleinberg J. (2009) Mapping the World's Photos. In Proceedings of the $18^{\text {th }}$ International WWW Conference (pp. 761770). New York: Association for Computing Machinery (ACM).

Crang, M. (1997) Picturing practices: research through the tourist gaze. Progress in Human Geography, 21(3), 359-373.

Crompton, J.L. (1979) An Assessment of the Image of Mexico as a Vacation Destination and the Influence of Geographical Location upon the Image. Journal of Travel Research, 17(4), 18-23. 
Dann, G.M.S. (1996) Tourists' images of a destination - An alternative analysis. Journal of Travel and Tourism Marketing, 5(1/2), 41-55.

Dilley, R.S. (1986) Tourists brochures and tourist images. Canadian Geographer, 30, 59-65.

Donaire, J.A., \& Galí, N. (2011) Barcelona Tourism image within the Flickr community. Cuadernos de Turismo, 27, 1061-1063.

Echtner, C.M., \& Ritchie, J.R.B. (1991) The Meaning and Measurement of Destination Image. The Journal of Tourism Studies, 14(1), 37-48.

Fakeye, P.C., \& Crompton, J.L. (1991) Image Differences Between Prospective, First-Time and Repeat Visitors to the Lower Rio Grande Valley. Journal of Travel Research, 30(2), 10-16.

Galí, N. (2006) La humanización de las imágenes emitidas por la publicidad de los destinos turísticos monumentales: el caso de Girona. Pasos, revista de turismo y patrimonio cultural, 3(2), 273-281.

Galí, N., \& Donaire, J.A. (2005) The social construction of the image of Girona: a methodological approach. Tourism Management, 26(5), 777-785.

Garrod, B. (2008) Exploring place perception. A Photo-based Analysis. Annals of Tourism Research, 35(2), 381-401.

Garrod, B. (2009) Understanding the relationship between Tourism Destination Imagery and Tourist Photography. Journal of Travel Research, 47, 346-358.

Gartner, W.C. (1994) Image Formation Process. Journal of Travel and Tourism Marketing, 2(2-3), 191-216. 
Govers, R., \& Go, F.M. (2005) Projected destination image online: Website content analysis of pictures and text. Information Technology \& Tourism, 7, 73-89.

Griffone, R., \& Weiler, B. (1992) The Learning Experience on Educational Travel Programs: A Case Study of Travel Learn Australia. In B. Weiler (Ed.), Ecotourism: Incorporating the Global Classroom. International Conference Papers (pp. 265-270). Canberra: Bureau of Tourism Research.

Gunn, C.A. (1972) Vacationscape. Designing Tourist Regions. Washington DC: Taylor \& Francis and University of Texas.

Gunn, C.A. (1988) Vacationscape: Designing tourist regions. New York: Van Nostraud Reinhold.

Hair, J.F. (1998) Multivariate data analysis. London: Prentice-Hall.

Hall, S. (1997) The spectacle of the other. In S. Hall (Ed.), Representation: cultural representations and signifying practices. London: Sage.

Hall, C.M., \& Valentin, A. (2005) Content Analysis. In B.W. Ritchie, P. Burns, \& C. Palmer (Eds.), Tourism Research Methods: Integrating Theory with Practice. Wallingford, UK: Cabi Publishing.

Harrison, B. (2004) Snap Happy: Toward A Sociology of "Everyday" Photography. In C.J. Pole (Ed.), Seeing is Believing? Approaches to Visual Research (pp. 23-39). (Studies in Qualitative Methodology, Volume 7). Emerald Group Publishing Limited.

Haywood, K.M. (1990) Visitor-employed photography: an urban visit assessment. Journal of Travel Research, 29(1), 25-29.

Holsti, O.R. (1968) Content Analysis. In G. Lindzey, \& E. Aronson (Eds.), The handbook of Social Psychology, 2 (pp. 596 692). Reading, Mass: Addison-Wesley. 
Jekins, O.H. (1999) Understanding and measuring tourist destination images. International Journal of Tourism Research, 1(1): 1-15.

Jenkins, O.H. (2003) Photography and Travel Brochures: The Circle of Representation. Tourism Geographies, 5(3), 305-328.

Kassarjian, H.H. (1977) Content analysis in consumer research. Journal of Consumer Research, 4, 8-18.

Kolbe, R.H., \& Burnett, M.S. (1991) Content-analyses research: An examination of applications with directives for improving research reliability and objectivity. Journal of Consumer Research,18, 243-250.

Kotler, P., Haider, D.H., \& Rein, I. (1994) Mercadotecnia de Localidades. Mexico: Diana.

Leisen, B. (2001) Image segmentation: the case of a tourism destination. Journal of Services Marketing, 15(1), 49-66.

Lo, I.S., McKercher, B., Lo, A., Cheung, C., \& Law, R. (2011) Tourism and online photography. Tourism Management, 32, 725-731.

Mackay, K.J., \& Couldwell, C.M. (2004) Using Visitor-Employed Photography to Investigate Destination Image. Journal of Travel Research, 42, 390-396.

Mackay, K.J., \& Fesenmaier, D.R. (1997) Pictorial elements of destination in image formation. Annals of tourism Research, 24(3), 537-565.

MacKay, K.J., \& Fesenmaier, D.R. (2000) An Exploration of Cross-Cultural Destination Image Assessment. Journal of Travel Research, 38(4), 417-423.

Markwell, K. (1997) Dimensions of photography in a Nature- Based Tour. Annals of Tourism Research, 28(2), 417-438. 
Markwick, M. (2001) Postcards from Malta: Image, Consumption, Context. Annals of Tourism Research, 28(2), 417-438.

Pan, B., \& Li, X. (2011) The long tail of destination image and online marketing. Annals of Tourism Research, 38(1), 132 -152

Pengiran-Kahar, D.I.N-F., Syed-Ahmad, S.F., Syed Ismail, S.H., \& Murphy, J. (2010) Shared Arabian Muslim Travel Photos. In U. Gretzel, R. Law, \& M. Fuchs (Eds.), Information and Communication Technologies in Tourism 2010. Proceedings of the International Conference ENTER 2010 (pp. 543-554). Wien: Springer-Verlag.

Popescu, A., Grefenstette, G., \& Moëllic, P.A. (2009) Mining tourist information from user-supplied collections. Proceedings of the 18th ACM conference on Information and knowledge management, 1713-1716.

Prebensen, N.K. (2007) Exploring tourists' images of a distant destination. Tourism Management, 28, 747-756.

Pritchard, A., \& Morgan, N.J. (1995) Evaluating vacation destination brochure images: The case of local authorities in Wales. Journal of Vacation Marketing, 2, 2338.

Pritchard, A., \& Morgan, N.J. (1996) Selling the Celtic Arc to the USA: a comparative analysis of the destination brochure image used in the marketing of Ireland, Scotland and Wales. Journal of Vacation Marketing, 2(4), 346-365.

Santos, J. (1998) The role of tour operators' promotional material in the formation of destination image and consumer expectations: The case of the People's Republic of China. Journal of Vacation Marketing, 4(3), 282-297.

Saïd, E. (1978) Orientalism. New York: Pantheon.

Schmallegger, D., \& Carson, D. (2008) Blogs in tourism: Changing approaches to information exchange. Journal of Vacation Marketing, 14, 99-110. 
Sontag, S. (1973) On Photography. New York: Farrar, Strauss and Giroux.

Stabler, M.J. (1988) The Image of Destination Regions: Theoretical and Empirical Aspects. In B. Goodall, \& G. Ashworth (Eds.), Marketing in the Tourism Industry: The Promotion of Destination Regions (pp. 133-161). London: Croom Helm.

Stepchenkova, S., \& Zhan, F. (2012) Visual destination images of Peru: Comparative content analysis of DMO and user-generated photography. Tourism Management, 36, 590-601. Doi: 10.1016/j.tourman.2012.08.006

Stylianou-Lambert, T. (2012) Tourists with Cameras: Reproducing or Producing. Annals of Tourism Research, 39(4), 1817-1838.

Urry, J. (1990) The Tourist Gaze. London: Sage.

Urry, J. \& Larsen, J. (2011). The Tourist Gaze 3.0. London: Sage. 
Figure (including maps and photographs)

Figure 1. Boí Valley Map

Para ver esta película, debe disponer de QuickTime ${ }^{\mathrm{TM}}$ y de un descompresor. 
Figure 2 . Tourists (\%) who photographed a minimum of one element by categories

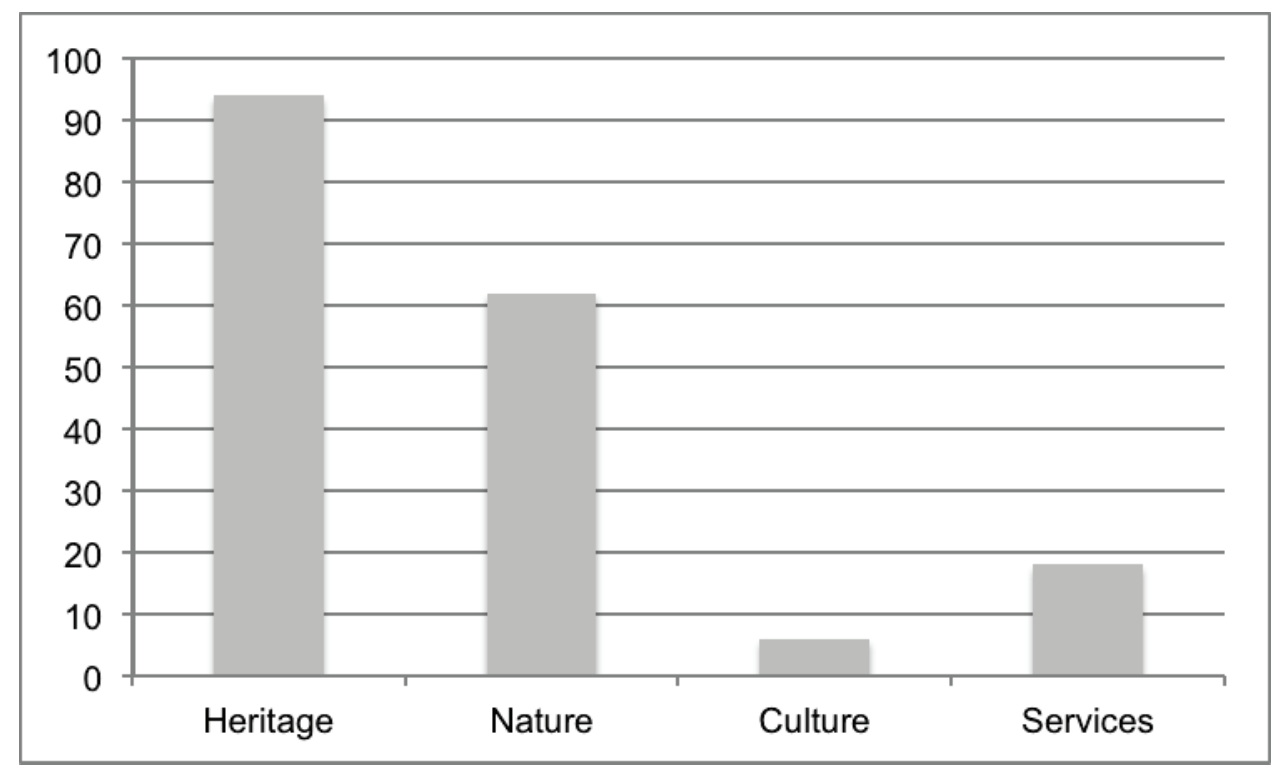


Table 1: Description of categories

\begin{tabular}{|l|l|}
\hline Categories & Description \\
\hline Nature & Includes landscape views, flora and fauna. \\
\hline Heritage & $\begin{array}{l}\text { Contains historical buildings, churches, monuments, and so } \\
\text { on. }\end{array}$ \\
\hline Culture & Focuses on all form of local culture, traditions and festivals. \\
\hline Tourist services & $\begin{array}{l}\text { Comprises all forms of tourism infrastructure and facilities } \\
\text { such as accommodation, restoration, attractions, etc. }\end{array}$ \\
\hline
\end{tabular}


Table 2: Items analyzed in content analysis

\begin{tabular}{|l|l|}
\hline Items & Authors \\
\hline Categories & $\begin{array}{l}\text { Camprubí, Guia \& Comas (2012); Dilley } \\
(1986) \text {; Galí \& Donaire (2005); Govers \& } \\
\text { Go (2005); Pritchard \& Morgan (1995); } \\
\text { Santos (1997) }\end{array}$ \\
\hline Degree of human presence & $\begin{array}{l}\text { Albers \& James (1988); Caton \& Santos } \\
(2008) ; \text { Choi, Letho \& Morrison (2007); } \\
\text { Galí (2005); Garrod (2009); Jenkins } \\
(2003) ; \quad \text { Pritchard \& Morgan (1995; } \\
1996) ; \text { Stylianou-Lambert (2012) }\end{array}$ \\
\hline Zoom & \begin{tabular}{l} 
Garrod (2009); Donaire \& Galí (2011) \\
\hline Interior/exterior
\end{tabular} \\
\hline
\end{tabular}


Table 3. Tourists (\%) by degree of human presence in photographs taken

\begin{tabular}{|l|l|}
\hline Human presence & $\mathbf{\%}$ \\
\hline Photographs with no people & 54 \\
\hline Photographs with no people + photographs with tourists & 30 \\
\hline Photographs with no people + photographs with tourists + with locals & 6 \\
\hline Photographs with no people + only with tourists + mixed (tourists and locals) & 2 \\
\hline Photographs with no people + photographs with locals & 4 \\
\hline All types of photographs & 4 \\
\hline Total & 100 \\
\hline
\end{tabular}


Table 4. Tourists (\%) according to how they took the photograph (focus)

\begin{tabular}{|l|l|}
\hline Zoom & $\mathbf{\%}$ \\
\hline Fragment & 14 \\
\hline Element & 29 \\
\hline Element in context & 33 \\
\hline Space - scenery & 24 \\
\hline Total & 100 \\
\hline
\end{tabular}


Table 5. Cluster analysis results

\begin{tabular}{|l|l|l|l|l|l|l|}
\hline & $\begin{array}{l}\text { Cluster } \\
\text { A }\end{array}$ & $\begin{array}{l}\text { Cluster } \\
\text { B }\end{array}$ & $\begin{array}{l}\text { Cluster } \\
\text { C }\end{array}$ & $\begin{array}{l}\text { Cluster } \\
\text { D }\end{array}$ & F & $\begin{array}{l}\text { p- } \\
\text { value }\end{array}$ \\
\hline Nature & 47.8 & 74.3 & 0.3 & 2.0 & 48.895 & .000 \\
\hline Heritage & 46.0 & 24.4 & 99.7 & 98.0 & 64.265 & .000 \\
\hline No people & 88.9 & 71.8 & 96.6 & 98.1 & 4.667 & .006 \\
\hline Fragment & 13.9 & 2.1 & 41.3 & 1.3 & 19.868 & .000 \\
\hline Element & 38.3 & 10.7 & 27.4 & 33.2 & 3.495 & .003 \\
\hline Context & 25.4 & 20.2 & 29.1 & 63.6 & 10.735 & .000 \\
\hline Space & 22.3 & 67.6 & 2.2 & 2.0 & 69.215 & .000 \\
\hline Interior & 7.7 & 0.2 & 31.4 & 0 & 18.826 & .000 \\
\hline
\end{tabular}




\section{Short bio}

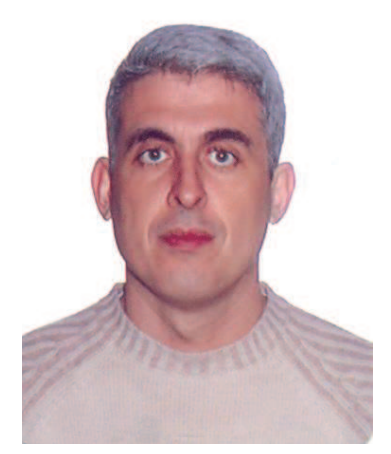

José A. Donaire holds a PhD in Geography and has been associate professor at University of Girona, since 1997. Currently, he is also the Director of the Research Institute of Tourism (INSETUR) at University of Girona. He has done research at University of Montreal (1993), the University of Tunis (1994), the University of Alberta (1996) and the University of Toulouse (2000). He has taken part in diverse research projects related to territorial management. His latest projects have focused on the study of local tourism policies within the field of destination management, the tourism image of destinations and visitors' behaviour in heritage cities and sites. 


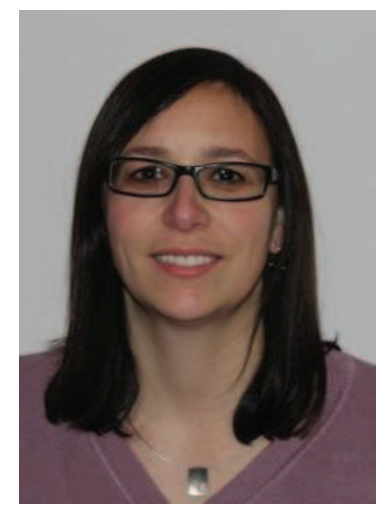

Raquel Camprubí was lecturer at University of Girona form 2004 to 2010 and has been Associate Professor at University of Girona, since then. She completed her PhD in 2009, focusing on tourism image formation and relational networks. She graduated in Tourism at University of Girona and Maîtrise in Ingenerie et commercialisation des produits touristiques from University of Toulouse - Le Mirail. Her research interests cover destination management, tourism image and branding. She is member of the research group Organizational Networks and Innovation in Tourism (ONIT). 


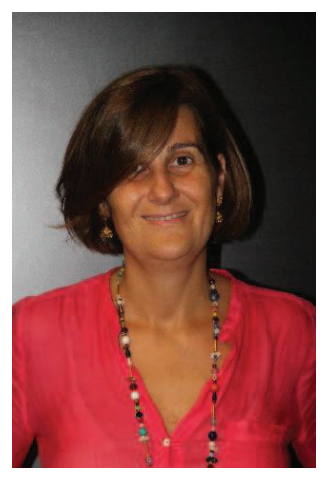

Núria Galí has been associate professor in the Faculty of Tourism at University of Girona since 1999. She holds a PhD in Heritage Tourism, and graduated in Humanities from the Universitat Autonoma of Barcelona and Maîtrise in Ingenerie et commercialisation des produits touristiques from the University of Toulouse - Le Mirail. She has been also co-director of a tourism research group (Multidisciplinary Laboratory of Tourism Research), since 2010. Her principal lines of research are: the study and analysis of the visitors' behaviour in heritage cities and sites, and the study and analysis of the tourism image of destinations. 